\title{
Seven New Drimane-Type Sesquiterpenoids from Cultures of Fungus Phellinus tuberculosus
}

\author{
Jiang-Bo He $\cdot$ Tao Feng $\cdot$ Shen Zhang $\cdot$ \\ Ze-Jun Dong $\cdot$ Zheng-Hui Li $\cdot$ Hua-Jie Zhu \\ Ji-Kai Liu
}

Received: 2 December 2013/ Accepted: 6 January 2014/Published online: 25 January 2014

(C) The Author(s) 2014. This article is published with open access at Springerlink.com

\begin{abstract}
Seven new drimane-type sesquiterpennoids, phellinuins A-G (1-7), together with one known compound $3 \beta, 11,12$-trihydroxydrimene (8) were isolated from the cultures of mushroom Phellinus tuberculosus. Their structures were elucidated on the basis of NMR and MS spectroscopic data and by comparison with data reported in the literature.

Keywords Phellinus tuberculosus · Drimane-type sesquiterpennoids · Phellinuins A-G
\end{abstract}

\section{Introduction}

Phellinus is a genus of fungi in the family Hymenochaetaceae. Many species cause white rot. Its fruiting bodies, often growing on wood, are resupinate, sessile, and perennial. The flesh is tough and woody or cork-like, and brown in color [1]. The fungus Phellinus tuberculosus has a wide distribution in Yunnan province of China [2]. The crude extract of mushroom $P$. tuberculosus was reported to possess antioxidant activity, which exhibited potent radical scavenging activity [3]. However, the chemical constituents of $P$. tuberculosis has not reported yet. As our continuous search for natural products from higher fungi [4-7], we carried out the chemical investigation on cultures of $P$.

Electronic supplementary material The online version of this article (doi:10.1007/s13659-014-0002-x) contains supplementary material, which is available to authorized users.

J.-B. He $\cdot$ T. Feng $\cdot$ S. Zhang $\cdot$ Z.-J. Dong $\cdot$ Z.-H. Li ·

H.-J. Zhu · J.-K. Liu ( $₫)$

State Key Laboratory of Phytochemistry and Plant Resources in West China, Kunming Institute of Botany, Chinese Academy of Sciences, Kunming 650201, People's Republic of China e-mail: jkliu@mail.kib.ac.cn

J.-B. He $\cdot$ S. Zhang

University of Chinese Academy of Sciences, Beijing 100049,

People's Republic of China tuberculosus, which resulted in the isolation of seven new drimane-tpye sesquiterpennoids named phellinuins $A-G$ (1-7) and one known compound (8) (Fig. 1). The structures of new compounds were determined on the basis of extensive spectroscopic analysis including NMR, MS, IR data, while the known compound was identified as $3 \beta, 11,12$-trihydroxydrimene (8) by comparison with data reported in literature [8]. This paper describes their isolation and structural elucidation.

\section{Results and Discussion}

Compound 1 was obtained as a colorless oil. Its molecular formula $\mathrm{C}_{15} \mathrm{H}_{26} \mathrm{O}_{4}$ was revealed on the basis of the HREIMS at $m / z, 270.1827$ (calcd for $\mathrm{C}_{15} \mathrm{H}_{26} \mathrm{O}_{4}, 270.1831[\mathrm{M}]^{+}$), suggesting three degrees of unsaturation. The ${ }^{1} \mathrm{H}$ NMR (Table 1) and ${ }^{13} \mathrm{C}$ NMR data (Table 2) shows the presence of two methyls, six methylenes, four methines, and three quaternary carbons. In addition, the IR spectrum showed the presence of hydroxy group $\left(3405 \mathrm{~cm}^{-1}\right)$. Apart from one double bond, the remaining two degrees of unsaturation in $\mathbf{1}$ were assumed to be a bicyclic sesquiterpenoid. Detailed analysis of NMR data suggested that compound 1 should be a drimane-type sesquiterpenoid with a similar planar structure to that of $3 \alpha, 11,15$-trihydroxydrimene [9]. Analysis of 2D NMR data suggested that only Me-12 was 


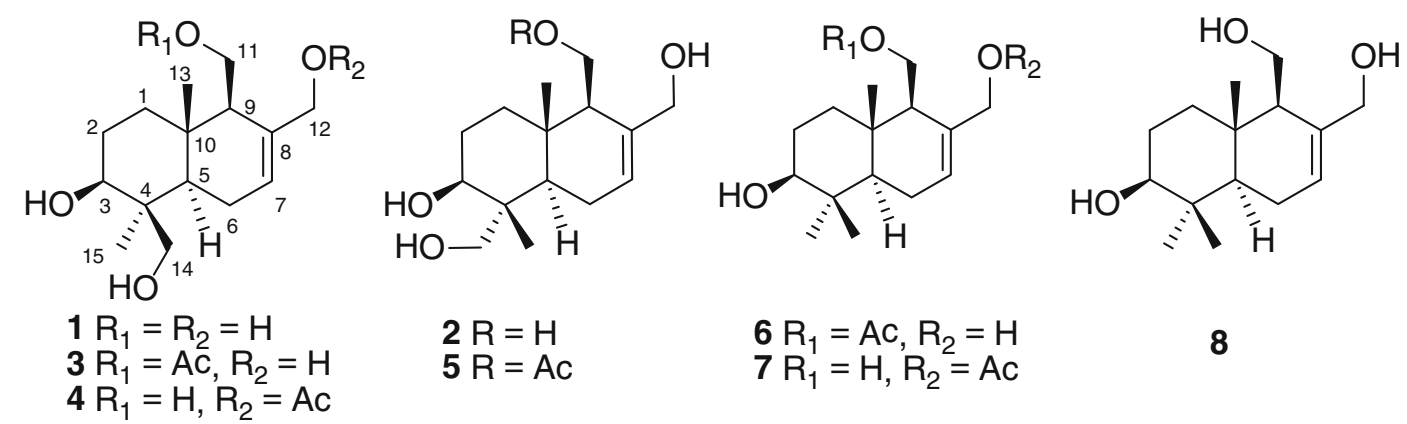

Fig. 1 Structures of compounds 1-8

Table $1{ }^{1} \mathrm{H}$ NMR data (600 MHz) of compounds 1-7 in methanol- $d_{4}$

\begin{tabular}{|c|c|c|c|c|c|c|c|}
\hline No. & $\mathbf{1}^{\mathrm{a}}$ & $2^{\mathrm{a}}$ & $3^{\mathrm{a}}$ & $4^{\mathrm{a}}$ & $\mathbf{5}^{\mathrm{a}}$ & $6^{\mathrm{b}}$ & $7^{\mathrm{a}}$ \\
\hline \multirow[t]{2}{*}{1} & $2.08, \mathrm{dt}(13.8,3.0)$ & 2.03 , overlap & 2.08 , overlap & 2.08 , overlap & $2.00, \mathrm{~m}$ & $2.01, \mathrm{~m}$ & $2.03, \mathrm{~m}$ \\
\hline & 1.32 , overlap & $1.29, \operatorname{td}(13.8,3.6)$ & 1.32 , overlap & 1.32 , overlap & $1.27, \mathrm{~m}$ & $1.29, \mathrm{~m}$ & $1.29, \mathrm{~m}$ \\
\hline \multirow[t]{2}{*}{2} & $1.80, \mathrm{~m}$ & $1.66, \mathrm{~m}$ & $1.80, \mathrm{~m}$ & $1.80, \mathrm{~m}$ & $1.67, \mathrm{~m}$ & $1.63, \mathrm{~m}$ & $1.63, \mathrm{~m}$ \\
\hline & $1.75, \mathrm{~m}$ & & $1.75, \mathrm{~m}$ & $1.75, \mathrm{~m}$ & & & \\
\hline 3 & $3.39, \mathrm{dd}(11.8,3.6)$ & $3.65, \mathrm{dd}(11.6,4.2)$ & $3.39, \mathrm{dd}(11.7,3.6)$ & $3.39, \mathrm{dd}(12.0,3.6)$ & $3.63, \mathrm{dd}(12.0,4.8)$ & $3.20, \mathrm{dd}(13.8,7.8)$ & $3.20, \mathrm{dd}(12.6,4.8)$ \\
\hline 5 & 1.35 , dd $(12.6,4.8)$ & $1.63, \mathrm{~m}$ & $1.35, \mathrm{dd}(12.6,4.8)$ & $1.35, \mathrm{dd}(12.6,4.8)$ & 1.63 , overlap & $1.25, \mathrm{~m}$ & $1.23, \mathrm{dd}(10.8,4.8)$ \\
\hline \multirow[t]{2}{*}{6} & $2.16, \mathrm{~m}$ & 2.04 , overlap & $2.16, \mathrm{~m}$ & $2.16, \mathrm{~m}$ & 2.03 , overlap & $2.08, \mathrm{~m}$ & $2.07, \mathrm{~m}$ \\
\hline & $1.95, \mathrm{t}(3.6)$ & & $1.97, \mathrm{t}(3.6)$ & $1.95, \mathrm{t}(3.6)$ & & & \\
\hline 7 & $5.77, \mathrm{t}(3.0)$ & 5.79, br. s & 5.82, br. s & 5.82, br. s & 5.83 , br. s & 5.85 , br. s & 5.84 , br. s \\
\hline 9 & 2.05 , overlap & 2.07 , overlap & 2.23 , br. s & 1.99 , overlap & 2.24, br. s & 2.22 , br. s & 1.97, br. s \\
\hline \multirow[t]{2}{*}{11} & 3.83 , dd $(10.8,3.0)$ & 3.85 , dd $(10.8,3.0)$ & $4.30, \mathrm{dd}(12.0,4.2)$ & $3.82, \mathrm{dd}(10.8,4.8)$ & $4.32, \mathrm{dd}(11.4,4.2)$ & $4.31, \mathrm{dd}(11.4,4.2)$ & 3.82 , dd $(10.8,3.6)$ \\
\hline & 3.62 , dd $(11.4,7.2)$ & 3.62 , dd $(11.4,7.2)$ & 4.20 , overlap & $3.58, \mathrm{dd}(10.8,6.6)$ & $4.21, \mathrm{dd}(11.4,6.0)$ & $4.20, \mathrm{dd}(11.4,6.0)$ & 3.58 , dd $(10.8,6.6)$ \\
\hline \multirow[t]{2}{*}{12} & $4.23, \mathrm{~d}(11.8)$ & $4.25, \mathrm{~d}(12.6)$ & $4.05, \mathrm{~d}(12.6)$ & $4.70, \mathrm{~d}(12.6)$ & $4.06, \mathrm{~d}(12.6)$ & $4.06, \mathrm{~d}(12.6)$ & $4.70, \mathrm{~d}(12.6)$ \\
\hline & $3.95, \mathrm{~d}(11.8)$ & 3.97, d (12.6) & $3.95, \mathrm{~d}(12.6)$ & $4.53, \mathrm{~d}(12.6)$ & 3.97, d (12.6) & 3.97, d (12.6) & $4,54, \mathrm{~d}(12.6)$ \\
\hline 13 & $0.79, \mathrm{~s}$ & $0.84, \mathrm{~s}$ & $0.84, \mathrm{~s}$ & $0.80, \mathrm{~s}$ & $0.90, \mathrm{~s}$ & $0.86, \mathrm{~s}$ & $0.82, \mathrm{~s}$ \\
\hline \multirow[t]{2}{*}{14} & $4.19, \mathrm{~d}(11.4)$ & $0.77, \mathrm{~s}$ & $4.19, \mathrm{~d}(11.4)$ & $4.19, \mathrm{~d}(11.4)$ & $0.80, \mathrm{~s}$ & $0.87, \mathrm{~s}$ & $0.86, \mathrm{~s}$ \\
\hline & $3.48, \mathrm{~d}(11.4)$ & & $3.48, \mathrm{~d}(11.4)$ & $3.48, \mathrm{~d}(11.4)$ & & & \\
\hline \multirow[t]{2}{*}{15} & $1.20, \mathrm{~s}$ & $3.48, \mathrm{~d}(10.8)$ & $1.20, \mathrm{~s}$ & $1.20, \mathrm{~s}$ & $3.49, \mathrm{~d}(10.8)$ & $0.98, \mathrm{~s}$ & $0.98, \mathrm{~s}$ \\
\hline & & $3.25, \mathrm{dd}(10.8)$ & & & $3.25, \mathrm{~d}(10.8)$ & & \\
\hline OAc & & & $2.01, \mathrm{~s}$ & $2.01, \mathrm{~s}$ & $2.02, \mathrm{~s}$ & $2.01, \mathrm{~s}$ & $2.03, \mathrm{~s}$ \\
\hline
\end{tabular}

a Spectra were measured at $600 \mathrm{MHz}$

${ }^{\mathrm{b}}$ Spectra were measured at $500 \mathrm{MHz}$

oxygenated into an oxymethylene in $\mathbf{1}$, which was suggested by the HMBC correlations from $\delta_{\mathrm{H}} 4.23(1 \mathrm{H}, \mathrm{d}$, $J=11.8 \mathrm{~Hz}, \mathrm{H}-12 \mathrm{a})$ and $3.95(1 \mathrm{H}, \mathrm{d}, J=11.8 \mathrm{~Hz}$, $\mathrm{H}-12 \mathrm{~b})$ to $\delta_{\mathrm{C}} 138.7$ (s, C-8). The HMBC data further supported that the other parts of the planar structure of $\mathbf{1}$ were the same to those of $3 \alpha, 11,15$-trihydroxydrimene (Fig. 2) [9]. In the ROESY spectrum (Fig. 2), the correlation of $\mathrm{H}-5 / \mathrm{Me}-15$ suggested that $\mathrm{C}-14$ was $\beta$ oriented, while the correlation of $\mathrm{Me}-15 / \mathrm{H}-3$, as well as the constant coupling of $\mathrm{H}-3$ (dd, $J=11.8,3.6 \mathrm{~Hz}$ ), indicated $\mathrm{OH}-3$ to be $\beta$ oriented. On the basis of these data, the ROESY correlations of $\mathrm{H}-5 / \mathrm{H}-9$ and $\mathrm{Me}-13 / \mathrm{H}-11$ indicated that $\mathrm{H}-9$ was $\alpha$ oriented, while Me-13 was $\beta$ oriented. Therefore, compound 1 was established as 3 $\beta, 11,12,14$-tetrahydroxydrimene and named as phellinuin A.

Compound 2 was isolated as amorphous powder. The molecular formula was established to be $\mathrm{C}_{15} \mathrm{H}_{26} \mathrm{O}_{4}$ on the basis of the HREIMS at $\mathrm{m} / \mathrm{z} 270.1828$ (calcd for $\mathrm{C}_{15} \mathrm{H}_{26} \mathrm{O}_{4}, 270.1831[\mathrm{M}]^{+}$). The 1D NMR data (Tables 1 and 2) were very similar to those of compound $\mathbf{1}$, which indicated that both compounds had the same structure. However, the ROESY correlations of $\mathrm{H}-5 / \mathrm{H}-15$ and $\mathrm{H}-15 / \mathrm{H}-3$ indicated that Me-15 was oxygenated into an oxymethylene in 2, while C-14 should be a methyl (Fig. 2). Detailed analyses of other 2D NMR data suggested that the other parts of $\mathbf{2}$ were the same to those of 
Table $2{ }^{13} \mathrm{C}$ NMR data of compounds 1-7 in methanol- $d_{4}$

\begin{tabular}{|c|c|c|c|c|c|c|c|}
\hline No. & $\mathbf{1}^{\mathrm{a}}$ & $2^{\mathrm{a}}$ & $3^{\mathrm{a}}$ & $4^{a}$ & $5^{\mathrm{a}}$ & $6^{\mathrm{b}}$ & $7^{\mathrm{a}}$ \\
\hline 1 & $38.8, \mathrm{CH}_{2}$ & 38.6, $\mathrm{CH}_{2}$ & $38.9, \mathrm{CH}_{2}$ & $38.8, \mathrm{CH}_{2}$ & 38.7, $\mathrm{CH}_{2}$ & $38.9, \mathrm{CH}_{2}$ & $39.0, \mathrm{CH}_{2}$ \\
\hline 2 & $28.8, \mathrm{CH}_{2}$ & 27.8, $\mathrm{CH}_{2}$ & $28.8, \mathrm{CH}_{2}$ & 28.7, $\mathrm{CH}_{2}$ & 27.7, $\mathrm{CH}_{2}$ & 28.6, $\mathrm{CH}_{2}$ & $28.8, \mathrm{CH}_{2}$ \\
\hline 3 & $81.4, \mathrm{CH}$ & 73.7, CH & $81.3, \mathrm{CH}$ & $81.3, \mathrm{CH}$ & 73.5, CH & $79.5, \mathrm{CH}$ & 79.7, CH \\
\hline 4 & $43.1, \mathrm{C}$ & $43.6, \mathrm{C}$ & 43.1, C & $43.0, \mathrm{C}$ & 43.6, C & $39.8, \mathrm{C}$ & $39.9, \mathrm{C}$ \\
\hline 5 & $51.7, \mathrm{CH}$ & 43.0, $\mathrm{CH}$ & $51.6, \mathrm{CH}$ & $51.1, \mathrm{CH}$ & 43.0, $\mathrm{CH}$ & $50.7, \mathrm{CH}$ & $50.8, \mathrm{CH}$ \\
\hline 6 & $24.4, \mathrm{CH}_{2}$ & $24.0, \mathrm{CH}_{2}$ & $24.4, \mathrm{CH}_{2}$ & 24.5, $\mathrm{CH}_{2}$ & $24.0, \mathrm{CH}_{2}$ & $24.2, \mathrm{CH}_{2}$ & 24.5, $\mathrm{CH}_{2}$ \\
\hline 7 & $126.2, \mathrm{CH}$ & $126.3, \mathrm{CH}$ & 126.7, $\mathrm{CH}$ & $128.8, \mathrm{CH}$ & 126.7, CH & 126.7, $\mathrm{CH}$ & $129.1, \mathrm{CH}$ \\
\hline 8 & 138.7, C & $138.5, \mathrm{C}$ & $137.4, \mathrm{C}$ & $134.4, \mathrm{C}$ & 137.2, C & $137.2, \mathrm{C}$ & $134.3, \mathrm{C}$ \\
\hline 9 & $55.8, \mathrm{CH}$ & $55.7, \mathrm{CH}$ & $52.2, \mathrm{CH}$ & $55.7, \mathrm{CH}$ & $52.1, \mathrm{CH}$ & $52.1, \mathrm{CH}$ & $55.8, \mathrm{CH}$ \\
\hline 10 & $36.5, \mathrm{C}$ & $36.4, \mathrm{C}$ & $36.8, \mathrm{C}$ & $36.6, \mathrm{C}$ & $36.7, \mathrm{C}$ & $36.9, \mathrm{C}$ & $36.8, \mathrm{C}$ \\
\hline 11 & $61.3, \mathrm{CH}_{2}$ & $61.4, \mathrm{CH}_{2}$ & 63.6, $\mathrm{CH}_{2}$ & $60.9, \mathrm{CH}_{2}$ & 63.6, $\mathrm{CH}_{2}$ & $63.5, \mathrm{CH}_{2}$ & $60.9, \mathrm{CH}_{2}$ \\
\hline 12 & $66.8, \mathrm{CH}_{2}$ & 67.0, $\mathrm{CH}_{2}$ & $65.8, \mathrm{CH}_{2}$ & 68.6, $\mathrm{CH}_{2}$ & $65.9, \mathrm{CH}_{2}$ & $65.7, \mathrm{CH}_{2}$ & 68.7, $\mathrm{CH}_{2}$ \\
\hline 13 & $16.1, \mathrm{CH}_{3}$ & $15.7, \mathrm{CH}_{3}$ & $16.1, \mathrm{CH}_{3}$ & $16.0, \mathrm{CH}_{3}$ & $15.8, \mathrm{CH}_{3}$ & $15.1, \mathrm{CH}_{3}$ & $15.0, \mathrm{CH}_{3}$ \\
\hline 14 & $65.0, \mathrm{CH}_{2}$ & 12.6, $\mathrm{CH}_{3}$ & 65.0, $\mathrm{CH}_{2}$ & $65.0, \mathrm{CH}_{2}$ & 12.6, $\mathrm{CH}_{3}$ & $15.9, \mathrm{CH}_{3}$ & 16.1, $\mathrm{CH}_{3}$ \\
\hline 15 & $23.3, \mathrm{CH}_{3}$ & 66.6, $\mathrm{CH}_{2}$ & $23.3, \mathrm{CH}_{3}$ & $23.3, \mathrm{CH}_{3}$ & $66.5, \mathrm{CH}_{2}$ & $28.0, \mathrm{CH}_{3}$ & $28.2, \mathrm{CH}_{3}$ \\
\hline OAc & & & $21.2, \mathrm{CH}_{3}$ & 21.1, $\mathrm{CH}_{3}$ & 21.2, $\mathrm{CH}_{3}$ & $21.1, \mathrm{CH}_{3}$ & 21.1, $\mathrm{CH}_{3}$ \\
\hline OAc & & & $173.0, \mathrm{C}$ & $173.0, \mathrm{C}$ & $173.0, \mathrm{C}$ & $172.9, \mathrm{C}$ & $173.0, \mathrm{C}$ \\
\hline
\end{tabular}

a Spectra were measured at $150 \mathrm{MHz}$

b Spectra were measured at $125 \mathrm{MHz}$

1. Therefore, the structure of compound 2 was established as $3 \beta, 11,12,15$-tetrahydroxydrimene and named phellinuin $\mathrm{B}$.

Compound 3, a colorless oil, possessed a molecular formula $\mathrm{C}_{17} \mathrm{H}_{28} \mathrm{O}_{5}$, as deduced from HREIMS at $\mathrm{m} /$ z 312.1935 (calcd for $\mathrm{C}_{17} \mathrm{H}_{28} \mathrm{O}_{5}, 312.1937[\mathrm{M}]^{+}$). The IR spectrum displayed the absorption bands for $\mathrm{C}=\mathrm{O}$ $\left(1722 \mathrm{~cm}^{-1}\right)$, OH $\left(3418 \mathrm{~cm}^{-1}\right)$, and $\mathrm{C}=\mathrm{C}\left(1642 \mathrm{~cm}^{-1}\right)$. All the NMR data suggested that compound $\mathbf{3}$ was closely related to $\mathbf{1}$ except one more $O$-acetyl group in 3. The $O$ acetyl group was substituted at $\mathrm{C}-11$-as revealed by HMBC correlations from $\delta_{\mathrm{H}} 4.30(1 \mathrm{H}, \mathrm{dd}, J=12.0$, $4.2 \mathrm{~Hz}, \mathrm{H}-11 \mathrm{a})$ and $4.20(1 \mathrm{H}$, overlap, $\mathrm{H}-11 \mathrm{~b})$ to $\delta_{\mathrm{C}} 173.0$ (s, OAc) and 52.2 (d, C-9). The other 2D NMR data suggested that the other parts of $\mathbf{3}$ were the same to those of $\mathbf{1}$ (Fig. 2). Thus, the structure of compound $\mathbf{3}$ was elucidated as phellinuin $\mathrm{C}$ as shown in Fig. 1.

Compound 4 was also obtained as a colorless oil. HREIMS gave one pseudomolecular ion at $\mathrm{m} / \mathrm{z} 312.1947$ (calcd for $\mathrm{C}_{17} \mathrm{H}_{28} \mathrm{O}_{5}, 312.1937$ ). The 1D NMR data (Tables 1 and 2) were very similar with those of compound 3. However, the HMBC correlations from $\delta_{\mathrm{H}} 4.70(1 \mathrm{H}, \mathrm{d}$, $J=12.6 \mathrm{~Hz}, \mathrm{H}-12 \mathrm{a})$ and $4.53(1 \mathrm{H}, \mathrm{d}, J=12.6 \mathrm{~Hz}$, $\mathrm{H}-12 \mathrm{~b}$ ) to $\delta_{\mathrm{C}} 134.4$ (s, C-8) and 173.0 (s, OAc) suggested that the $O$-acetyl group was substituted at $\mathrm{C}-12$ in 4 rather than at $\mathrm{C}-11$ in 3 . The other parts of structure 4 were established to be the same with those of $\mathbf{3}$ by 2D NMR correlations (Fig. 2). Therefore, compound 4 was identified as phellinuin $\mathrm{D}$.
Compound 5 was established as an $O$-acetyl derivative of $\mathbf{2}$, which was supported by the HMBC correlations from $\delta_{\mathrm{H}} 4.32(1 \mathrm{H}, \mathrm{dd}, J=11.4$ and $4.2 \mathrm{~Hz}, \mathrm{H}-11 \mathrm{a})$ and 4.21 $(1 \mathrm{H}, \mathrm{dd}, J=11.4$ and $6.0 \mathrm{~Hz}, \mathrm{H}-11 \mathrm{~b})$ to $\delta_{\mathrm{C}} 137.2$ (s, C-8) and 173.0 (s, OAc). The other 2D NMR data suggested that the others parts of $\mathbf{5}$ were the same to those of $\mathbf{2}$. Therefore, the structure of compound $\mathbf{5}$ was established and named as phellinuin E.

Compounds 6 and 7 were identified as $O$-acetyl analogues of the known compound 3 $\beta, 11,12$-trihydroxydrimene (8) [8]. The HMBC data suggested that the $O$-acetyl group was substituted at C-11 in 6 and C-12 in 7, respectively (Fig. 2). Analyses of other 2D NMR data suggested that the other parts were the same to those of 8 (Fig. 2). Therefore, the structures of compounds 6 and 7 were established and named as phellinuin $\mathrm{F}(\mathbf{6})$ and phellinuin $\mathrm{G}$ (7), respectively.

\section{Experimental Section}

\subsection{General Experimental Procedures}

Optical rotations were measured on a Jasco-P-1020 polarimeter. IR spectra were obtained by using a Bruker Tensor 27 FT-IR spectrometer with $\mathrm{KBr}$ pellets. NMR spectra were acquired with instruments of Avance III 600 and Bruker DRX-500. HREIMS were measured on a waters autoSpec Primier P776 instruments. Silica gel (200-300 


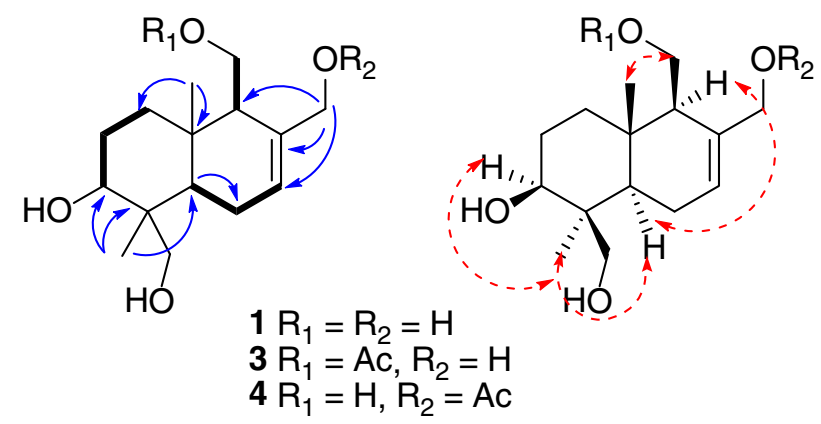

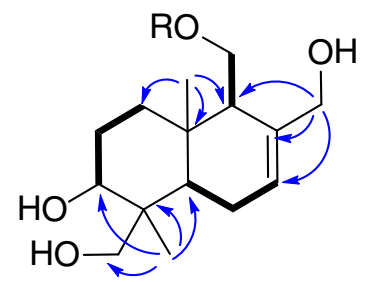

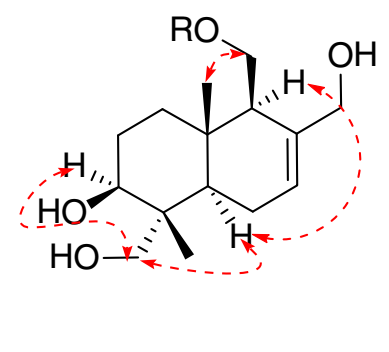

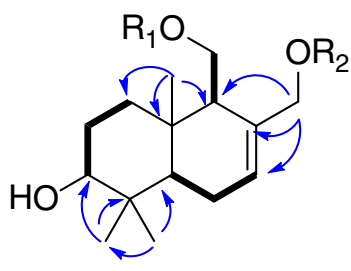

$6 \mathrm{R}_{1}=\mathrm{Ac}, \mathrm{R}_{2}=\mathrm{H}$
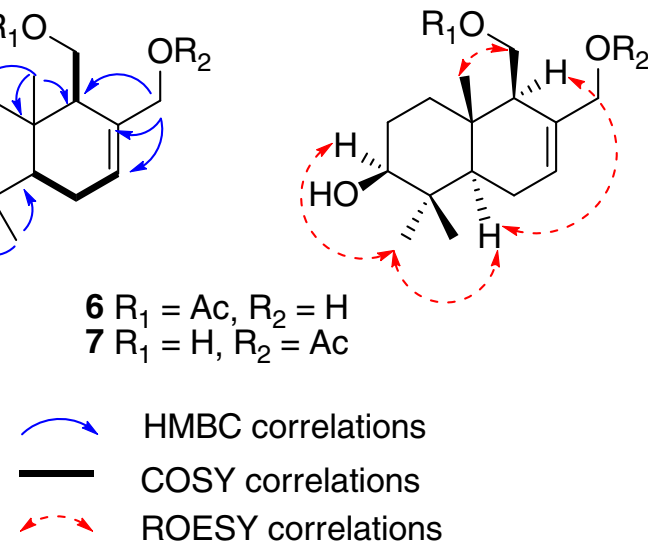

Fig. 2 The main HMBC, COSY, and ROESY correlations of 1-7

mesh, Qingdao Marine Chemical Inc., China) and Sephadex LH-20 (Amersham Biosciences, Sweden) were used for column chromatography (CC). Fractions were monitored by TLC and spots were visualized by heating silica gel plates immersed in vanillin- $\mathrm{H}_{2} \mathrm{SO}_{4}$ in $\mathrm{EtOH}$, in combination with Agilent 1200 series HPLC system (Eclipse XDB-C18 column, $5 \mu \mathrm{m}, 4.6 \times 150 \mathrm{~mm}$ ).

\subsection{Material and Cultural Conditions}

Fruiting bodies of Phellinus tuberculosus were collected at Jingdong, Yunnan Province, China in 2003 and identified by Prof. Zhu-Liang Yang of Kunming Institute of Botany, CAS. The voucher specimen (NO.CGBWSHF00118) was deposited at herbarium of Kunming Institute of Botany. Culture medium: glucose $(5 \%)$, pork peptone $(0.15 \%)$, yeast $(0.5 \%), \mathrm{KH}_{2} \mathrm{PO}_{4}(0.05 \%), \mathrm{MgSO}_{4}(0.05 \%)$, The initial $\mathrm{pH}$ was adjusted to 6.0 , the fermentation was first carried out on an Erlenmeyer flask for 6 days till the mycelium biomass reached to the maximum. Later it was transferred to a fermentation tank $(20 \mathrm{~L})$ at $24{ }^{\circ} \mathrm{C}$ and $250 \mathrm{rpm}$ for 20 days, ventilation was set to $1.0 \mathrm{vvm}$ (vvm: air volume/culture volume/min).

\subsection{Extraction and Isolation}

The culture broth $(20 \mathrm{~L})$ was concentrated under vacuum, extracted three times with EtOAc. The organic layer was evaporated in vacuum to give a crude extract $(3.1 \mathrm{~g})$, which was separated by Sephadex LH-20 (MeOH) CC to afford fractions A-C. Fraction B (2.5 g) was separated by reversed-phased $\mathrm{C} 18$ column $\left(\mathrm{MeOH}-\mathrm{H}_{2} \mathrm{O}, 30-100 \%\right)$ to give sub-fractions $\mathrm{B} 1$ and $\mathrm{B} 5$. The sub-fraction $\mathrm{B} 1$ $(110 \mathrm{mg})$ was further purified by silica gel $\left(\mathrm{CHCl}_{3}-\mathrm{MeOH}\right.$, 20/1) to yield $1(5.8 \mathrm{mg})$, Fraction B2 was separated by Sephadex LH-20 (MeOH) to obtain B2-1 $(50 \mathrm{mg})$, which was further isolated and purified by silica gel $\mathrm{CC}\left(\mathrm{CHCl}_{3}\right.$ $\mathrm{MeOH}, 20 / 1)$ to obtain $2(31.6 \mathrm{mg})$. Fraction B3 was purified by Sephadex LH-20 (MeOH) and silica gel $\left(\mathrm{CHCl}_{3}-\mathrm{MeOH}, 30 / 1\right)$ to get $5(2.2 \mathrm{mg})$ and $8(8.6 \mathrm{mg})$. The sub-fraction B4 was purified by preparative HPLC $\left(\mathrm{MeOH}-\mathrm{H}_{2} \mathrm{O}, 40 \%, 10 \mathrm{~mL} / \mathrm{min}\right)$ to obtain $3(7.9 \mathrm{mg})$ and 4 (2.5 mg). Fraction B5 was separated by Sephadex LH-20 $(\mathrm{MeOH})$ column chromatography, then further separated on silica gel $\left(\mathrm{CHCl}_{3}-\mathrm{MeOH}, 30 / 1\right)$ to give $6(17.4 \mathrm{mg})$ and 7 (1.0 mg).

Phellinuin A (1): colorless oils, $[\alpha]_{\mathrm{D}}^{17.3}-10.3(c 0.1$ $\mathrm{MeOH}$ ); IR (KBr) $v_{\max } 3405,2963,2930,2871,1665$, $1443 \mathrm{~cm}^{-1}$; ${ }^{1} \mathrm{H}$ NMR data (see Table 1); ${ }^{13} \mathrm{C}$ NMR data (see Table 2); ESIMS (neg.) $m / z 539$ [2M - H] ${ }^{-}$; HREIMS $m / z 270.1827[\mathrm{M}]^{+}$(calcd for $\mathrm{C}_{15} \mathrm{H}_{26} \mathrm{O}_{4}, 270.1831$ ).

Phellinuin B (2): amorphous powder, $[\alpha]_{\mathrm{D}}^{20.6} 0(c) 0.3$ $\mathrm{MeOH}) ; \mathrm{IR}(\mathrm{KBr}) v_{\max } 3345,2930,2878,1666,1442,1057$, $1983 \mathrm{~cm}^{-1} ;{ }^{1} \mathrm{H}$ NMR data (see Table 1 ); ${ }^{13} \mathrm{C}$ NMR data (see Table 2); ESIMS (pos.) $\mathrm{m} / \mathrm{z} 539[2 \mathrm{M}-\mathrm{H}]^{-}$; HREIMS $m / z 270.1828[\mathrm{M}]^{+}\left(\right.$calcd for $\left.\mathrm{C}_{15} \mathrm{H}_{26} \mathrm{O}_{4}, 270.1831\right)$.

Phellinuin C (3): colorless oil, $[\alpha]_{\mathrm{D}}^{20.6}-4.2$ (c 0.2 $\mathrm{MeOH})$; IR (KBr) $v_{\max } 3418,2966,2933,2859,1722,1642$, 1454, 1385, $1256 \mathrm{~cm}^{-1}$; ${ }^{1} \mathrm{H}$ NMR data (see Table 1 ); ${ }^{13} \mathrm{C}$ NMR data (see Table 2); ESIMS (pos.) $m / z 335[\mathrm{M}+\mathrm{Na}]^{+}$; HREIMS $m / z 312.1935[\mathrm{M}]^{+}$(calcd for $\mathrm{C}_{17} \mathrm{H}_{28} \mathrm{O}_{5}, 312.1937$ ).

Phellinuin D (4): colorless oil, $[\alpha]_{\mathrm{D}}^{20.8}-5.4$ (c 0.3 $\mathrm{MeOH}$ ); IR (KBr) $v_{\max } 3421,2961,2932,2858,1736,1631$, 1443, 1384, $1254 \mathrm{~cm}^{-1}$; ${ }^{1} \mathrm{H}$ NMR data (see Table 1); ${ }^{13} \mathrm{C}$ NMR data (see Table 2); ESIMS (pos.) $m / z, 335[\mathrm{M}+\mathrm{Na}]^{+}$; HREIMS $m / z 312.1947[\mathrm{M}]^{+}$(calcd for $\mathrm{C}_{17} \mathrm{H}_{28} \mathrm{O}_{5}, 312.1937$ ).

Phellinuin E (5): colorless oil, $[\alpha]_{\mathrm{D}}^{21.1}+5.6(c 0.002$ $\mathrm{MeOH})$; IR (KBr) $v_{\max } 3424,2932,2891,1736,1634$, $1456 \mathrm{~cm}^{-1}$; ${ }^{1} \mathrm{H}$ NMR data (see Table 1 ); ${ }^{13} \mathrm{C}$ NMR data (see Table 2); ESIMS (pos.) $m / z 335[\mathrm{M}+\mathrm{Na}]^{+}$; HREIMS $m / z 312.1930[\mathrm{M}]^{+}$(calcd for $\mathrm{C}_{17} \mathrm{H}_{28} \mathrm{O}_{5}, 312.1937$ ). 
Phellinuin F (6): colorless oil, $[\alpha]_{\mathrm{D}}^{20.4}-2.8$ (c 0.4 $\mathrm{MeOH})$; IR (KBr) $v_{\max } 3441,2965,2931,2857,1737,1639$, $1442 \mathrm{~cm}^{-1}$; ${ }^{1} \mathrm{H}$ NMR data (see Table 1 ); ${ }^{13} \mathrm{C}$ NMR data (see Table 2); ESIMS (pos.) $\mathrm{m} / \mathrm{z} 319[\mathrm{M}+\mathrm{Na}]^{+}$; HREIMS $\mathrm{m} / \mathrm{z} 296.1986[\mathrm{M}]^{+}$(calcd for $\mathrm{C}_{17} \mathrm{H}_{28} \mathrm{O}_{4}, 296.1988$ ).

Phellinuin G (7): colorless oil, $[\alpha]_{\mathrm{D}}^{20.4}-6.5$ (c 0.1 $\mathrm{MeOH})$; IR (KBr) $v_{\max } 3442,2933,2869,1721,1665,1460$, $1254 \mathrm{~cm}^{-1}$; ${ }^{1} \mathrm{H}$ NMR data (see Table 1$) ;{ }^{13} \mathrm{C}$ NMR data (see Table 2); ESIMS (pos.) $\mathrm{m} / z, 4319[\mathrm{M}+\mathrm{Na}]^{+}$; HREIMS $\mathrm{m} / \mathrm{z}, 296.1982[\mathrm{M}]^{+}$(calcd for $\mathrm{C}_{17} \mathrm{H}_{28} \mathrm{O}_{4}, 296.1988$ ).

Acknowledgments This work was financially supported by National Natural Sciences Foundation of China (U1132607) and Youth Innovation Promotion Association, CAS (2011312D11019).

Open Access This article is distributed under the terms of the Creative Commons Attribution License which permits any use, distribution, and reproduction in any medium, provided the original author(s) and the source are credited.

\section{References}

1. J.B. Ellis, M.B. Ellis, Fungi Without Gills (Hymenomycetes and Gasteromycetes): An Identification Handbook (Chapman and Hall, London, 1990)

2. X.X. Zhang, Y.C. Dai, China Flora 29, 111 (2005)

3. P. Seephonkai, S. Samchai, A. Thongsom, S. Sunaart, B. Kiemsanmuang, K. Chakuton, Zhongguo Tianran Yaowu 9, 441-445 (2011)

4. J.H. Ding, T. Feng, B.K. Cui, K. Wei, Z.H. Li, J.K. Liu, Tetrahedron Lett. 21, 2651-2654 (2013)

5. X.Y. Yang, T. Feng, Z.H. Li, Y. Sheng, X. Yin, J.K. Liu, Org. Lett. 14, 5382-5384 (2012)

6. S. Wang, L. Zhang, L.Y. Liu, Z.J. Dong, Z.H. Li, J.K. Liu. Nat. Prod. Bioprospect. 2, 240-244 (2012)

7. S. Wang, Z.H. Li, Z.J. Dong, J.K. Liu, T. Feng, Fitoterapia 91, 194-198 (2013)

8. J.R. Sierra, J.T. Lopez, M.J. Cortes, Phytochemistry 25, 253-254 (1986)

9. J.Y. Zhao, J.H. Ding, Z.H. Li, Z.J. Dong, T. Feng, H.B. Zhang, J.K. Liu, J. Asian Nat. Prod. Res. 15, 305-309 (2013) 